sending installation employs a microphone so constructed that the speech current is inverted with respect to frequency, so that it is unintelligible to the listener on an ordinary receiver. At the receiving end of the communication channel an equipment is used to turn the speech back to normal. From these brief details, it would appear that the system is similar to the inverted-speech method employed by the British Post Office for securing secrecy, as an alternative to the speech-scrambling method which has also been developed and used by the Post Office in long-distance radio-telephonic communication.

\section{Research on Lawns}

IT is gratifying to learn that the British Board of Greenkeeping Research will be enabled to maintain its Research Station at St. Ives, Bingley, Yorks, for a further period of five years. Vol. 10, No. 3 of the Board's Journal contains a review by the Director of the past four and a half years' work at the Station. There is also a continuation of the series of articles by Mr. I. G. Lewis, describing common grasses. Redtop (Agrostis stolonifera, L., var. gigantea, Koch) and velvet bent ( $A$. canina) are considered in the present volume. The former is somewhat coarse for fine lawns, but the latter is the queen of putting green orasses. Mr. Arthur Hill describes his experiments on lawns at Craibstone, whilst the Director of the Bingley Station, Mr. R. B. Dawson, continues his articles on "Common Weeds of Turf". Dr. T. W. Evans also contributes a paper on phosphatic fertilisers in relation to greenkeeping, and Mr. R. Gordon, of Prestwick Golf Club, writes on "A Golf Course under Seaside Conditions".

\section{Royal Society of New Zealand}

THE inaugural meeting of the newly formed Royal Society of New Zealand (hitherto called the New Zealand Institute) was held at Wellington on May 16, when the presidential address was delivered by Prof. R. Speight, professor of geology at Canterbury College, Christchurch, New Zealand. Lord Bledisloe, the Governor-General of New Zealand, in a written address to the Society, intimated His Majesty's approval of the new designation of the Dominion's chief organisation for the promotion of science. The New Zealand Institute was founded in 1867 and the fellowship of the new Society is held by forty-eight men of science. In his address, Lord Bledisloe emphasised the importance of science in solving the world's economic and social problems. Only by the further application of science in all its ramifications and a more enlightened recognition of its beneficent potentialities by the world's rulers will effective remedies for current human disorders be found. The New Zealand Institute has achieved a high prestige in a land of immeasurable opportunities for industrial and cultural expansion. It is therefore to be hoped that under its new appellation it will enjoy to an ever-increasing extent the confidence and respect of the community at large.

\section{Dorothy Temple Cross Fellowships in Tuberculosis}

The Medical Research Council has made the following awards of Dorothy Temple Cross Fellowships for 1934-35, under the terms of the benefaction in that name for research fellowships in tuberculosis : Mr. W. S. Creer, Lady Jones Orthopædic research fellow, University of Liverpool ; Mr. A. W. Franklin, chief assistant to Children's Department, St. Bartholomew's Hospital, London; Dr. P. D'A. Hart, assistant physician, University College Hospital, London ; Mr. A. Landau, house physician, Brompton Hospital, London: Mr. A. H. T. Robb-Smith, senior demonstrator of morbid anatomy, St. Bartholomew's Hospital, London. Mr. Robb-Smith's fellowship is tenable in Germany, the others at centres in the United States. In addition, the fellowship awarded last year to Dr. G. G. Kayne for work at centres in Europe has been renewed for a further period of six months.

\section{Books on Social History and Early Travel}

Messrs. Francis Edwards's Catalogue No. 572 of new and second-hand books on "History throughout the Ages" contains items of even more extended interest than the title suggests. Not only does it include source books, but also in its extra-European sections there are a number of early travel books and other works of value for their early records of ethnographical material. Among items of particular interest to the social historian is a remarkable run of the London Gazette, Nos. 1-4825, dating from November, 1665 to March 24, 1710, in thirteen folio volumes, in contemporary calf. The early numbers include notices of the Plague, indicating the rapid decrease then showing in the figures. The accounts of the Fire of London are followed by schemes for rebuilding the city. Another item of similar interest is Higden's "Polychronicon" in the Rolls Series, now partly out of print. Among official papers is a complete set of the reports of the Historical Manuscripts Commission to 1926. An editio princeps of the Nuremburg Chronicle in Gothic letter of 1493 contains 1800 woodcuts, among which appears a portrait of Pope Joan. Early travel books include Hakluyt in black letter, the "Relations" of the Jesuits in Canada (1858), Burney's South Seas, Callander's Australian voyages, Formander's "Account of the Polynesian Race", Dalrymple's voyages in the South Pacific and Kæmpfer's history of Japan.

\section{Percival Collection of Seeds of British Plants}

THE Department of Agricultural Botany of the University of Reading has acquired the Percival Collection of seeds of British plants. This collection, which took about forty years to put together, contains mounted and named seeds of more than a thousand species. Although the British flora is not completely represented, the collection is by far the most adequate in Great Britain and is invaluable for reference purposes. Prof. W. B. Brierley, professor of botany at Reading, hopes that field botanists will 
assist him in completing this collection and states that he will be glad to supply lists of the species still unrepresented.

\section{Royal Society of Medicine of Ghent}

THE centenary of the foundation of the Royal Society of Medicine of Ghent was celebrated on May 26 in the presence of some three hundred medical men from all parts of Belgium and France under the presidency of Dr. Van Cauwenberghe. The inaugural meeting, in which the history of the Society was related by the secretary, M. de Bersaques, was followed by a scientific gathering at which papers were read by Profs. Leriche of Strasbourg, Polak Daniels of Gröningen and Dr. Ragin of Lausanne.

\section{Announcements}

WE much regret to announce the death, at the age of seventy-nine years, of Dr. L. Cockayne, F.R.S., honorary botanist of the State Forest Service of New Zealand; and also of Dr. N. L. Britton, emeritus director of the New York Botanic Garden, on June 25, at the age of seventy-five years.

The Rogers Field Gold Medal of the Royal Sanitary Institute has been awarded to Imperial Chemical Industries Ltd., for an exhibit of Chloros at the Bristol Congress of the Institute just concluding. The medal is given for an exhibit of outstanding merit from the point of view of hygiene. The special features of the Chloros exhibit at Bristol were its uses in connexion with the sterilisation of rural water supplies and swimming pools.

ThE Secretary of State for the Colonies has ap. pointed Mr. A. C. Miles, provincial superintendent of agriculture, to be deputy director of agriculture, Gold Coast.

DR. R. C. Bowden, chemical engineer under the Director of Ordnance Factories, has been appointed by the War Office to be Superintendent, Royal Gunpowder Factory, Waltham Abbey, in succession to Lieut.-Col. P. H. Evans, Royal Artillery, who retires on July 12 .

THE trustees of the Bernhard Baron Charitable Trust have made a grant of $£ 10,000$ to the British Empire Cancer Campaign in response to its Empire Day appeal. The money will be put in a special fund to be called the "Bernhard Baron Cancer Fund".

THE annual Autumn Meeting of the Institute of Metals will be held at Manchester on September 3-6, under the chairmanship of Dr. Harold Moore, president of the Institute. On September 3, Dr. J. L. Haughton will deliver the thirteenth Autumn Lecture entitled: "The Work of Walter Rosenhain". Further information can be obtained from the secretary of the Institute, 36 Victoria Street, London, S.W.1.

IN 1920, Miss L. Jones-Bateman, of Cae Glass, Abergele, presented to the Royal Horticultural
Society a valuable silver-gilt replica of the Warwick vase to be used for the encouragement of fruit production. It has accordingly been decided to offer it triennially for researches in the growing of hardy fruits, figs, grapes and peaches in the open or under glass, and it is available for award in 1934. Candidates should submit accounts of their work by October 31. The work dealt with must have been carried out by the candidate in the United Kingdom mainly during the past five years.

Messrs. Longmans, Green and Co., Ltd. announce for publication in September a work by Mr. G. C. Robson, deputy keeper of zoology at the British Museum (Natural History), and Mr. O. W. Richards, lecturer in entomology at the Imperial College of Science and Technology, entitled "Variations of Animals in Nature". In this work the authors have summarised the evidence on the subject in an attempt to decide what evolutionary theory is in best agreement with the facts.

Applicatrons are invited for the following appoint. ments, on or before the dates mentioned :-A parttime assistant in statisties at the London School of Economics and Political Science, Houghton Street, Aldwych, W.C.2-The Secretary (July 17). An assistant lecturer in electrical engineering at the York Technical Institute-The Secretary for Education, Education Offices, Clifford Street, York (July 18). An assistant lecturer in the Department of Zoology, preferably a vertebrate morphologist, at University College, London, W.C.I-The Secretary (July 18). A head of the Department of Geology, Mineralogy and Geography at the Chelsea Polytechnic, London, S.W.3-The Principal (July 21). A lecturer (man) to take charge of the Post-Graduate Training Department of University College, Leicester-The Registrar (July 21). A lecturer in engineering at the Denbighshire Technical Institute, Wrexham-The Principal (July 21). A teacher of engineering at Leigh Municipal College The Director of Education, Town Hall, Leigh (July 21). An assistant lecturer in geography at University College, Exeter-The Registrar (July 28). A deputy director and bacteriologist at Adelaide Hospital, who will also be lecturer in bacteriology in the University-The Agent General for South Australia, Australia House, Strand, London, W.C.2 (Aug. 15). A biochemist or chemist, preferably with knowledge of physical chemistry and biology, for an investigation into the effect of oil upon mosquito larvæ, at the London School of Hygiene and Tropical Medicine, Keppel Street, W.C.1-The Secretary (Sept. 7). A professor of mathematics in Victoria University College, Wellington, New Zealand-The Secretary, Universities Bureau of the British Empire, 88a, Gower Street, London, W.C.1. Demonstrators in mechanical engineering, electrical engineering and communications, and physics, at Woolwich Poly. technic, London, S.E.18-The Secretary. A teacher of mining and engineering in East Kent-The Acting Principal, Technical Institute, Ladywell, Dover. 